\title{
Online Learning Program Evaluation to Improve the Education Quality in Primary School
}

\author{
Sintha Wahjusaputri', Faariq Robiith Al Khuwarizmi², Dwi Priyono3 \\ DOI: $10.35445 /$ alishlah.v13i3.659
}

\begin{abstract}
Article Info
Abstract

Keywords:

Discrepancy Evaluation

Model;

Online Learning;

Quality of Education;

This research aims to measure the effectiveness of online learning programs during the COVID-19 pandemic in improving the quality of education at one of the Islamic School in Jakarta. This study uses a qualitative descriptive method and a discrepancy evaluation model (DEM). The evaluation model was chosen to see the gap between standards and implementation in the field. These aspects include six stages of inequality evaluation, online learning principles, student learning outcomes, and characteristics of the quality of education. School management must always carry out strict supervision and monitoring so that online learning can run smoothly and effectively to minimize the possibility of gaps and achieve all the characteristics contained in the implementation standards. The results of this evaluation relate to the quality of education at Islamic schools.
\end{abstract}

Kata kunci:

Discrepancy Evaluation

Model;

Pembelajaran Online;

Kualitas Pendidikan

\section{Abstrak}

Tujuan dari penelitian ini adalah untuk mengukur efektivitas program pembelajaran online dimasa pandemic COVID-19 untuk meningkatkan kualitas pendidikan di salah satu sekolah islam di Jakarta. Penelitian ini menggunakan metode deskriptif kualitatif, dan model evaluasi diskrepansi (DEM). Model evaluasi dipilih untuk melihat kesenjangan antara standar dan implementasi di lapangan. Aspek-aspek tersebut meliputi enam tahapan evaluasi ketimpangan, prinsip pembelajaran online, hasil belajar siswa, dan karakteristik kualitas pendidikan. Manajemen sekolah harus selalu melakukan pengawasan dan pemantauan yang ketat agar pembelajaran online dapat berjalan dengan lancar dan efektif untuk meminimalkan kemungkinan terjadinya kesenjangan dan mencapai semua karakteristik yang ada dalam standar pelaksanaan. Hasil evaluasi ini berkaitan dengan kualitas pendidikan di sekolah islam tersebut.

\footnotetext{
${ }^{1}$ Un iv ersitas Mu hammadiyah Prof. DR. HAMKA, Ja karta, Indonesia

Em ail: sinthaw@uhamka.ac.id

2 Un iv ersitas Mu hammadiyah Prof. DR. HAMKA, Ja karta, Indonesia

Em ail: faariqrobith@gmail.com

3 Univ ersitas Muhammadiyah Prof. DR. HAMKA, Jakarta, In donesia

Em a il: dwipriyono@uhamka.ac.id
} 


\section{INTRODUCTION}

To prevent the Covid-19 pandemic, the government issued a policy to ask students to study at home. Some local governments have decided to implement policies to leave students and start implementing online learning methods. Starting March 16, 2020, the school applies the online student learning method, followed by other provincial areas. Online learning is now an alternative for educational institutions to provide learning materials. Teachers must ensure that teaching and learning activities continue, even though students are at home. The solution is that teachers are required to design learning media as an innovation by utilizing online media (Hodges, Moore, Lockee, Trust, \& Bond, 2020). This is by the Minister of Education and Culture of the Republic of Indonesia regarding Circular Letter Number 4 of 2020 concerning the Implementation of Education Policies in the Emergency Period for the Spread of Corona Virus Disease (COVID-19) (Ditjen GTK Kemendikbud, 2016).

The effectiveness of online learning conducted from one institution to another needs to be reviewed so that implementing agencies can evaluate it (Park, 2011). Thus one of the critical factors for learning effectiveness is the evaluation factor, both the process and the learning outcomes (Castro \& Tumibay, 2019). Evaluation can encourage students to learn more sustainably, encourage teachers to improve the learning process's quality, and encourage schools to improve other facilities and management quality (Setyawan, 2018). So, in this case, an evaluation needs to be done.

Mafatih Islamic School Kalibata, as one of the implementing online learning institutions, has several obstacles and gaps in its implementation. The obstacles that occur, it turns out, are some of the common obstacles in online learning implementing institutions. However, there are some gaps in terms of inequality in Mafatih Islamic School Kalibata, Jakarta, that may not occur in other institutions. Based on preliminary observation and interview with the Vice Principal of Mafatih Islamic School Kalibata, it has several obstacles, like some students who do not have learning tools. In addition, some students are less active/absent in learning. Some students are late in joining the lesson. Some material is missed, and some students are constrained on the internet/quota network, so they cannot participate in online learning.

The implementation of online Learning in Mafatih needs to be evaluated to know the level of effectiveness and the extent to which it impacts the school's efforts in maintaining the effectiveness of learning in its students. If it is not practical, the school can improve it. If it is effective, the school must maintain the level of effectiveness and increase it so that the implementation target is comprehensive to improve the quality of school education.

There are several studies have been conducted on the evaluation of online learning. According to Hamid, Sentryo, \& Hasan (2020), the primary support for online learning is network access and the device's ability to connect to the internet. This research also shows that the implementation of online learning has not been fully effective. According to Dabbagh and Ritland (A. Novita \& Abdul, 2015), learning online is open and spread learning system using pedagogical devices (educational aids). Online learning is made possible through the internet and networkbased technology to facilitate learning through meaningful actions and interactions (Pakpahan \& Fitriani, 2020). In addition, online learning can also be defined as technology-based learning materials where learning materials are sent electronically to remote learners using computer networks (Pangondian, Santosa, \& Nugroho, 2019). This research shows gaps and obstacles between government policies and implementation in Mafatih Islamic School Kalibata, an elementary school.

This research aims to obtain accurate information and objectives about online learning in Mafatih Islamic School Kalibata. Such information may be in the form of an implementation process programs, impacts/results achieved, efficiency, and utilization of evaluation results focused on the program itself, namely to make decisions whether resumed, repaired, or terminated (Wicks et al., 2015). In addition, it has been used as interest preparation for the next program and the 
preparation of policies related to the program (Gunawan, 2011). The benefit of the evaluation is to identify problems that will focus on measuring the achievement of learning programs in Mafatih Islamic School Kalibata and the alignment of online learning programs with government policies. (Oktaviyani \& Sukirlan, 2015).

\section{METHODS}

This research was conducted at Mafatih Islamic School, Jakarta, Indonesia. The approach used in this study is qualitative. This research evaluates the program using a method that focuses on one selected phenomenon and wants to be understood in depth. Furthermore, the research design model used is model discrepancy evaluation (DEM). Data collection techniques were used: interviews with school authorities (headmaster, teacher, and school director), students and parents, document studies, and observations. In this study, the researchers used miles and Huberman model data analysis, i.e., data analysis was conducted during data collection and after completing the data collection in a certain period. Activities in the data analysis model are subtraction data, display data, and image /verification conclusions.

\section{Data Reduction}

The data obtained from the field is quite a lot, for that it is necessary to record carefully and in detail. Reducing data means summarizing, choosing the main things, focusing on the essential things, looking for themes and patterns.

\section{Data Display}

Once the data is reduced, the next step is to display the data. Data presentation can be done in brief descriptions, charts, and relationships between categories in qualitative research.

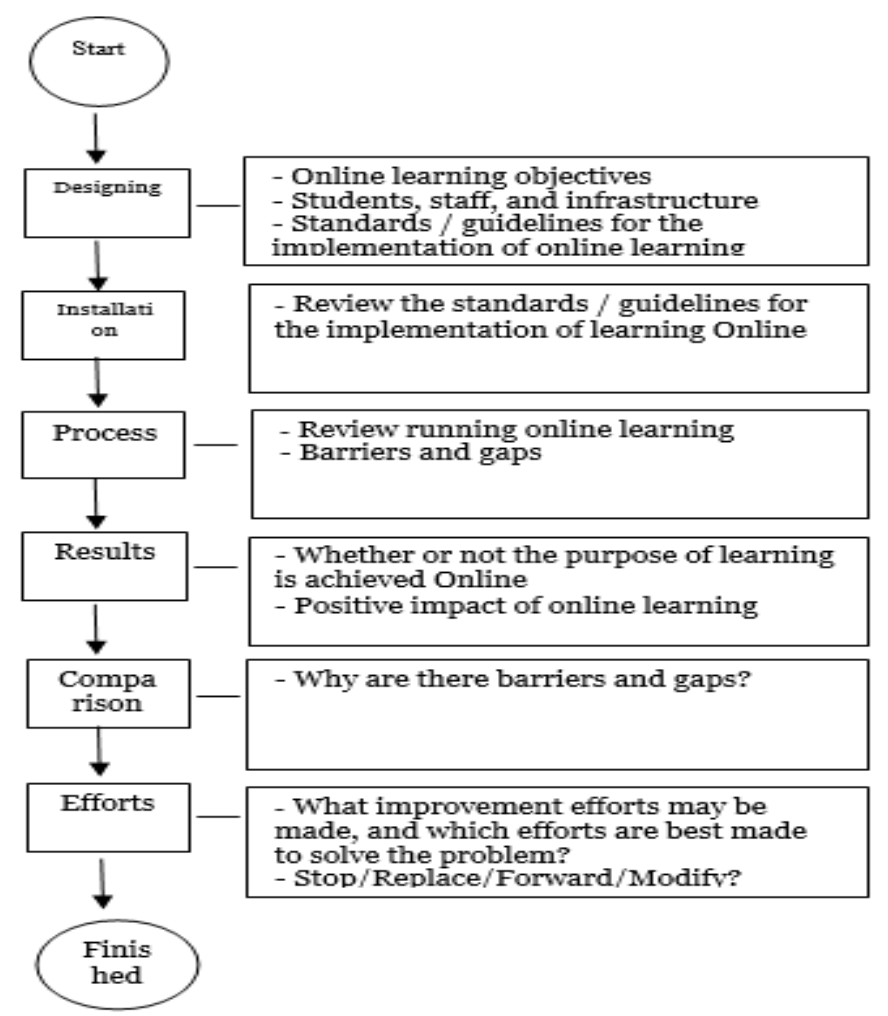

Figure 1. Research methods using DEM models 


\section{FINDINGS AND DISCUSSION}

The findings of this evaluation are the part that will explain the aspects studied, namely online learning, online learning objectives, availability of students, staff, and infrastructure, as well as standards or guidelines for implementing online learning (Kearns, 2012). In addition, researchers will also discuss a review of standards or guidelines for implementing online learning. In addition, it will also discuss ongoing online learning and obstacles and gaps in the implemented online learning. Then, the researcher will discuss whether or not online learning objectives have been achieved and the positive impact of online learning (Hosie, Schibeci, \& Backhaus, 2005). In the next stage, the causes of the existing barriers and gaps will be discussed. Then, the improvement efforts will be discussed at the final stage, and the final decision will be made. In addition, the researcher also conducted an analysis of the six stages, the principles of online Learning at Mafatih Islamic School Kalibata, and the quality characteristics of Mafatih Islamic School Kalibata's education.

\section{Designing}

Mafatih Islamic School Kalibata, is an institution that has carried out online learning since the March 2020. Through online learning, Mafatih Islamic School Kalibata wants his student's education rights to be fulfilled (besides the safety factor during this pandemic). The Human Resources in Mafatih Islamic School Kalibata are sufficient to support the online learning process. With adequate Human Resources, effective and efficient online Learning is more accessible for schools as organizers. On the other hand, a lack of human resources will lead to less effective and efficient online learning. Mafatih Islamic School Kalibata as the implementer of education, especially online learning in particular (school side), does not have obstacles in infrastructure. However, the problem comes from the side of the student/guardian. The obstacle is the network/quota used by students during online learning.

As for online learning, this new academic year, Mafatih Islamic School uses a combined model of e-learning (Moodle) as a place for material and several virtual meeting platforms and changes according to needs. At the beginning of online Learning, Mafatih used a Facebook Group. Then, in the new school year last July, Mafatih Islamic School created e-learning with the Moodle platform. Mafatih also increased virtual meetings with students to conduct learning using Zoom (initially) and switched to Google Meet and now Microsoft Teams. Mafatih also uses Jamboard and Microsoft Word to share screens.

In the implementation of online Learning, Mafatih Islamic School uses standards or guidelines issued by the government. The standards or guidelines are the Governor's Circular on implementing distance learning at home in March 2020 and the Learning From Home (BDR) guidelines issued by the Ministry of Education and Culture.

Thus, it is expected that online learning will be conducted effectively and efficiently to achieve online learning objectives in school. The number of human resources owned by the school is not much. However, it is enough to support learning online due to the small number of students. Concerning infrastructure facilities in schools, there are no constraints and support in implementing online learning in schools. Adequate infrastructure is one of the factors in the success of schools in carrying out learning. This is in line with a theory stating that facilities and infrastructure are also supporting factors in the learning process for teachers and students (Tomczyk, Potyrała, Włoch, Wnęk-Gozdek, \& Demeshkant, 2020). Without education, education will not be achieved according to the common objectives, so facilities and infrastructure influence learning success (Novita, 2017). Schools use standards or implementation guidelines issued by the Ministry of Education.

\section{Installation}

The school does not conduct a detailed review of the standards or guidelines used. This indeed triggers obstacles and gaps if the process and results do not match what the school expects. 
Conducting a detailed review of the standards or guidelines for implementing online learning can minimize obstacles and gaps in the process and the results.

\section{Process}

In general, online learning carried out by Mafatih Islamic School Kalibata runs smoothly. Online learning has been carried out since March 2020 and continues to this day. Although online learning is carried out smoothly, it cannot be denied that it cannot be separated from several obstacles. Among them are some students who do not have learning tools. Some students are less active in learning or are often absent in learning. Some students are late in joining the lesson so that some material is missed. Some students have problems with their internet quota/network.

The obstacles from the student's side are also the lack of student preparation in participating in learning. Some of them were not bathed, had not had breakfast when the lesson started. In addition, their position in participating in learning is sometimes arbitrary and at will. This can trigger their lack of course focus in learning, especially if they follow online learning while sleeping (Fletche, 2005).

There are also obstacles from the teacher's side. Some of these barriers are specific, and some are general. For those who are unique, one of the obstacles is the teacher's family situation. Then, for general barriers, one of them is that the teacher cannot know students' overall abilities in detail. Parents also have obstacles, where some parents complain that their children cannot focus and concentrate on what is conveyed by the teacher.

Another obstacle from the parents' side is that some parents do not supervise their children while learning. Some of them also happen to be working. Some may have an agenda that clashes with the child's learning. This can lead to less control of their children. Some of them whom their parents do not control experience difficulties in learning. Some obstacles from parents' side regarding supervision are related to their children's learning and the misuse of learning tools owned by their children (which should only be used for learning). Some of them play games during class hours. In addition, parents who do not control it also have not understood or have not taught their children, so they are constrained to control their learning devices and understand the learning carried out. As a result, the results obtained from the child in question are also unsatisfactory.

The school also feels that obstacles are felt by parents who are given information from the teacher about their child being less active or absent in learning. The school does not have the authority to ensure that the child has been reprimanded or advised. The school cannot ensure that the child in question listens and obeys what his parents say.

In addition to some of the obstacles above, there are also various gaps in the parents' families' economic side. Therefore, there will be differences in circumstances between guardians of students who are present and students whose economic side is lacking. The difference is, for example, the facilities used by their children in the implementation of online learning. This is because the economic status of the guardians of students at Mafatih Islamic School Kalibata is heterogeneous and not homogeneous. Of course, this can trigger obstacles and gaps between guardians of present students and those who are less.

The implementation of online learning in schools went smoothly. This is inseparable from the presence of some gaps and obstacles in it. If reviewed more deeply, some of the constraints and gaps occur, ranging from the lack of school reviews to standards or guidelines. In addition, the gap in information technology resources and facilities that have been observed during the COVI D-19 pandemic is a consequence of online education reform. According to Bdair (2021), students living in remote areas have problems with information technology facilities in implementing online learning. This should improve the school if it wants to do online learning again in the future. Thus, the gaps and obstacles that have occurred can be eliminated or at least minimized. 


\section{The Result of Measurement}

The online learning in Mafatih Islamic School Kalibata is quite good compared to some other schools. However, these results are not very good compared to face-to-face learning (outside the pandemic). One of the positive impacts that occur is the result of online learning conducted by the school. If online learning can be done better, it is possible to get maximized results, and the positive impacts will also be more and more widespread. According to Risalah et al. (2020), some of the positive impacts are children can explore technology from an early age, Online system makes the learning process more flexible, the student can save transportation expenses, the material can be saved and replayed if it is poorly understood, last is student can dig knowledge and resources. Some of the gaps and obstacles that occur are caused by almost all stakeholders in the school. Schools, parents, and students also have a role to play in the occurrence of gaps and obstacles. This needs to be improved so that online learning will be better and gaps and obstacles are not rediscovered.

\section{Comparison}

Online learning in schools has been going quite well, but there are still some obstacles and gaps that occur compared to face-to-face learning. One of the causes of the obstacles is that schools do not conduct a detailed review of the standards or guidelines for implementing online learning. This can trigger the possibility of obstacles and gaps in its implementation. In addition, one of the main factors that can affect the success and effectiveness of the online learning carried out is a collaboration between the school and the guardian of students. So, the school must provide an opportunity for the guardians of students to convey their complaints in online learning that their children follow. Furthermore, parents must accept all the inputs and directions given by the school. This is one of the most significant factors in online learning success because of the excellent cooperation between the school and the parents.

\section{Efforts}

The school has made various efforts to tackle gaps and barriers. Regarding the quota problem, the school opens alms quota for those in need. In addition, schools also provide opportunities for the guardians of the students who are constrained by a network in their home areas to attend schools online using school wifi. Related to children who are less active or absent and are also late in participating in learning, the teacher concerned parents or guardians of the students concerned about this through the WhatsApp chat. Some student guardians also provide input to schools as one of the efforts in responding to all existing gaps and obstacles. One of the inputs is that schools can make class management, where later teachers can divide their students into several groups, later each group will carry out learning with the teacher alternately with the duration of the specified time. This can minimize the musical students' learning because only a few children (divided into several groups).

The lesson plan change is needed where the school (the teacher) must make more interactive learning. Teachers must involve students more in learning. Students can be invited to play games (especially grades 1 to 3 ) and argue that it can attract students' attention to follow learning later. The teacher must also be wiser in determining the number of chapters to be learned by students. In a sense, if the normal state of the teacher teaches four chapters in one semester, in the state of Covid-19, the teacher must cut the number of chapters taught to 2 so that the learning given is genuinely compelling.

There is also input from the student guardian so that the child's learning account is automatically connected with e-mail or WhatsApp parents. The teacher can also provide evaluations/feedback every month related to students, tasks, and others so that parents can also evaluate at home and children are more controlled. Then, the teacher can randomly check the child's task or whisk to ensure that the child works on the task. The feedback and evaluation received from parents have been listed in the learning guide issued by the Ministry of Education and Culture. For example, there are listed "collect and recap the task sent by students in the agreed 
time." However, the Islamic School Mafatih Kalibata does not entirely do this due to a lack of detailed retribution to the standards or guidelines for implementing online learning. So, in this case, the school must conduct a detailed review of the standards and guidelines used. As for the final decision, if this online learning continues, the school is ready to re-apply. However, the school has not made any effort to conduct a detailed review of online learning standards or guidelines. This needs to be done if the school wants to implement online learning to meet the standards. The key to online learning success is the cooperation between the school and the parents.

Being creative can be obtained through the learning process. The rise of creativity can be influenced by a variety of factors, including communication factors between family (Gündüz, Alemdağ, Yaşar, \& Erdem, 2016). In this case, it is the parents, and the school, especially the teacher. Attitudes trust each other, help each other in guiding children, and communicate between parents and teachers. It will make the child feel they have to be creative and achieve success in learning. So the importance of families and teachers' roles in the formation and development of creativity means that the communication between parents and teachers must also be established well. Because with good communication, there is a synergy between the two (Pusitaningtyas, 2017). School is ready if later re-enacted online learning.

Table 1. Principles of Online Learning Implemented

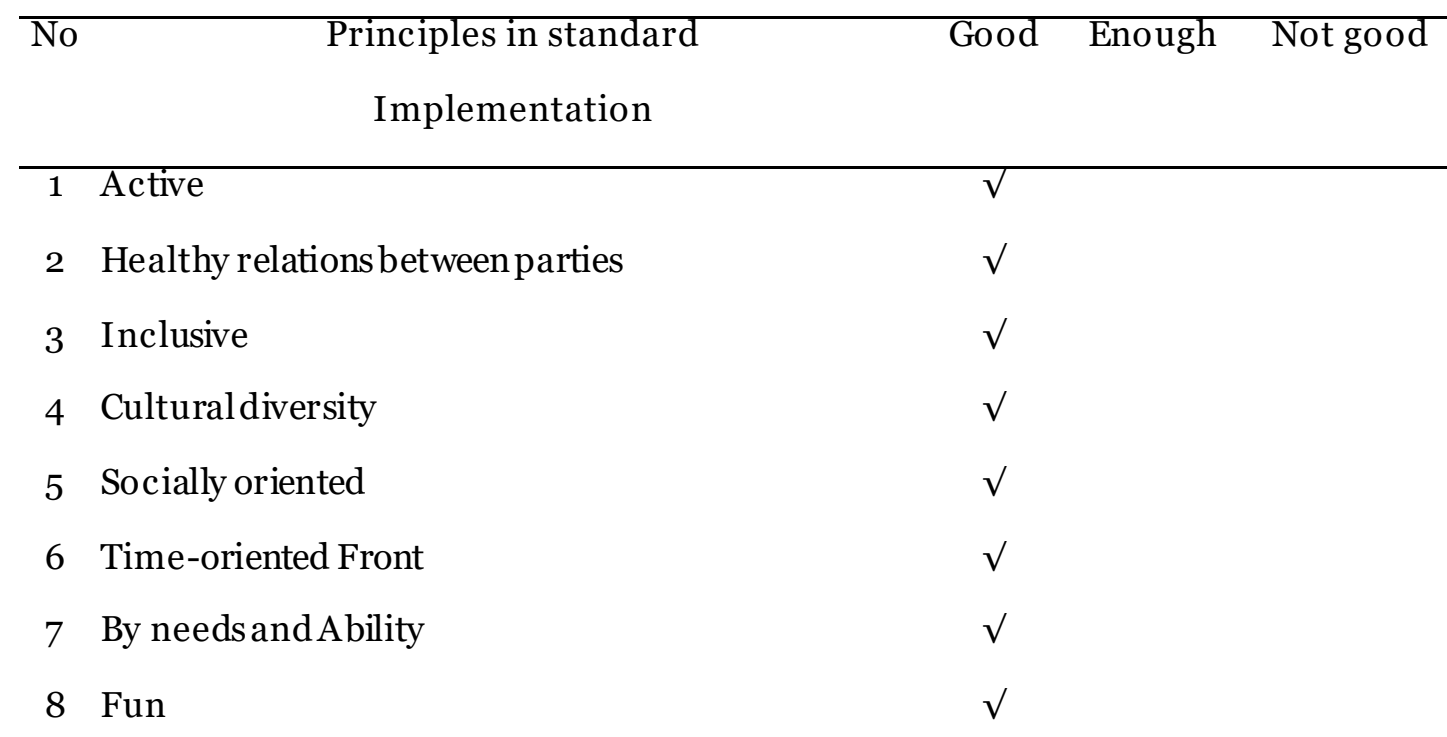

All principles set out in the standards or guidelines implementation have been fulfilled by the school. Especially for point number 7, because of parents' economic status in heterogeneous schools, the ability to intend there (if speaking from the economic side) is relatively also conditional. In a sense, schools can adjust plans and implementation with the economic status of the student's guardian. It is visible from various efforts made by the school in supporting its implementation processes, such as providing online facilities from schools for network-constrained students and others (Tsa, Tsa, \& Kuen-Yi Lin, 2015).

In the quality characteristics of education below, there is inequality in the three characteristics. On performance characteristics, some teachers do not routinely create a lesson plan. Some teachers do not learn on time in starting or ending learning on the characteristics of reasonable time. On specific standard characteristics, in online learning, schools use government standards as a reference. However, the lack of a detailed review makes some gaps and Obstacles (T. Page et al., 2008). It occurs due to the lack of supervision and monitoring of school management of all teachers. Management schools must always carry out strict monitoring and monitoring to online learning that is carried out smoothly and effectively to minimize gaps (Griff \& Matter, 2012). 
Table 2. The Quality of Characteristics in Mafatih Islamic School

\begin{tabular}{|c|c|c|c|c|}
\hline No & Characteristics & Good & Enough & Not good \\
\hline & Performance & & $\sqrt{ }$ & \\
\hline 2 & Reasonabletime & & $\sqrt{ }$ & \\
\hline 3 & Reliable & $\sqrt{ }$ & & \\
\hline 4 & Durability & $\sqrt{ }$ & & \\
\hline 5 & Beautiful & $\sqrt{ }$ & & \\
\hline 6 & Human relationships & $\sqrt{ }$ & & \\
\hline 7 & Easy to use & $\sqrt{ }$ & & \\
\hline 8 & Custom shapes & $\sqrt{ }$ & & \\
\hline 9 & Certain standards & & $\sqrt{ }$ & \\
\hline 10 & Consistency & $\sqrt{ }$ & & \\
\hline 11 & Uniform & $\sqrt{ }$ & & \\
\hline 12 & Ableto serve & $\sqrt{ }$ & & \\
\hline 13 & Accuracy & $\sqrt{ }$ & & \\
\hline
\end{tabular}

Student learning outcomes become one of the determinants of whether or not quality education at an educational institution (Dolan, Hancock, \& Wareing, 2015). With this online learning, the student's learning outcomes Mafatih Islamic School Kalibata shows that about $70 \%$ of students have achieved the standard minimal achievement. Approx 30\% of students who have not yet achieved the standard minimal achievement. However, 30\% of it is not all material, only a range of 1-3 materials per student. Thus, this study shows that the quality of education at Mafatih Islamic School Kalibata has been quite good, especially in implementing online learning.

\section{CONCLUSION}

In general, all aspects and criteria of evaluation are achieved. However, it would be better if the monitoring was conducted by the school management frequently. There is good cooperation between the school and the parents, and the school's efforts to review the standards used are further improved. However, several aspects and criteria have not been achieved, such as a detailed review of standards, several online learning targets that have not been achieved, and three characteristic qualities of education that have not been met. Therefore, the school must continually evaluate so that later online learning is done more effectively and helpful for the parties involved.

This research will have a positive and significant impact on the online learning program during the COVID-19 pandemic at this school if the parties optimize as much as possible in minimizing existing gaps and obstacles so that the positive impact of online learning that is carried out is more effective and widespread. Regardless, future research could continue to explore the alignment between national regulation of online learning and school's regulation, also the readiness of school's information technology facilities in implementing online learning. 


\section{REFERENCES}

Bdair, I. A. (2021). Nursing students' and faculty members' perspectives about online learning during COVID-19 pandemic: A qualitative study. Teaching and Learning in Nursing .

Castro, M. D. B., \& Tumibay, G. M. (2019). A literature review: efficacy of online learning courses for higher education institution using meta-analysis. Education and Information Technologie, 26.

Ditjen GTK Kemendikbud. (2016). Petunjuk teknis program peningkatan guru pembelajar moda dalam jaringan (Daring).

Dolan, E., Hancock, E., \& Wareing, A. (2015). An evaluation of online learning to teach practical competencies in undergraduate health science students. The Internet and Higher Education, 24, 21-25.

Fletche, K. M. (2005). Self-efficacy as an evaluation measure for programs in support of online learning literacies for undergraduates. The Internet and Higher Education, 8(4), 307-322.

Griff, E. R., \& Matter, S. F. (2012). Evaluation of an adaptive online learning system. British Journal of Educational Technology, 44(1), 170-176.

Gunawan, I. (2011). Evaluasi programpembelajaran.

Gündüz, A. Y., Alemdağ, E., Yaşar, S., \& Erdem, M. (2016). Design of a problem-based online learning environment and evaluation of its effectiveness. Turkish Online Journal of Educational Technology, 15(3), 49-57.

Hamid, R., Sentryo, I., \& Hasan, S. (2020). Online learning and its problems in the Covid-19 emergency period. Jurnal Prima Edukasia, 8(1), 86-95. https://doi.org/10.21831/jpe.v8i1.32165

Hodges, C., Moore, S., Lockee, B., Trust, T., \& Bond, A. (2020). Remote Teaching and Online Learning.

Hosie, P., Schibeci, R., \& Backhaus, A. (2005). A framework and checklists for evaluating online learning in higher education. Assessment \& Evaluation in Higher Education, 3O(5).

Kearns, L. (2012). Student Assessment in Online Learning: Challenges and Effective Practices. Jolt.Merlot.Org, $\quad 8(3), \quad 198-208 . \quad$ Retrieved from http://jolt.merlot.org/vol8no3/kearns_o912.htm

Novita, A., \& Abdul, H. (2015). Penggunaan media pembelajaran online - offline dan komunikasi interpersonal terhadap hasil belajar bahasa Inggris. Jurnal Teknologi Informasi \& Komunikasi Dalam Pendidikan, 2(1).

Novita, M. (2017). Sarana dan prasarana yang baik menjadi bagian ujung tombak keberhasilan lembaga pendidikan Islam.

Oktaviyani, A., \& Sukirlan, M. (2015). Evaluasi program pembelajaran bahasa Inggris kelas English for children di Smart Bandar Jaya.

Page, T., Thorsteinsson, G., ... Lehtonen, M. (2008). A Methodology For The Evaluation Of Online Learning Resources. I-Manager's Journal of Educational Technology, 4(4), 16-27. https://doi.org/10.26634/jet.4.4.574

Pakpahan, R., \& Fitriani, Y. (2020). Analisa pemanfaatan teknologi informasi dalam pembelajaranjarak jauh di tengah pandemi virus COVID-19.

Pangondian, R. A., Santosa, P. I., \& Nugroho, E. (2019). Faktor-faktor yang mempengaruhi kesuksesan pembelajarandaring dalam revolusi industri 4.o.

Park, J. Y. (2011). Design Education Online: Learning Delivery and Evaluation. International Journal of Art \& Design Education, 30(2), 176-187.

Pusitaningtyas, A. (2017). Pengaruh komunikasi orang tua dan guru terhadap kreativitas siswa. Proceedings of the ICECRS.

Risalah, A., Ibad, W., Maghfiroh, L., Azza, M. I., Cahyani, S. A., \& Ulfayati, Z. A. (2020). Dampak pandemi Covid-19 terhadap kegiatan belajar mengajar di MI/SD (Studi KBM berbasis daring 
bagi guru dan siswa). JIEES : Journal of Islamic Education at Elementary School, 1(1), 1016. Retrieved from https://doi.org/10.47400/jiees.v1i1.5

Setyawan, C. E. (2018). Desain evaluasiprogram pembelajaran bahasa Arab. 9.

Tomczyk, Ł., Potyrała, K., Włoch, A., Wnęk-Gozdek, J., \& Demeshkant, N. (2020). Evaluation of the functionality of a new e-learning platform vs. Previous experiences in e-learning and the self-assessment of own digital literacy. Sustainability (Switzerland), 12(23), 1-22. https://doi.org/10.3390/su122310219

Tsa, F.-H., Tsa, C.-C., \& Kuen-Yi Lin. (2015). The evaluation of different gaming modes and feedback types on game-based formative assessment in an online learning environment. Computers \& Education, 81, 259-269.

Wicks, D., Craft, B. B., Lee, D. D., Lumpe, A., Henrikson, R., \& Baliram, N. (2015). An Evaluation of Low Versus High Collaboration in Online Learning. Online Learning, 19(4). 